\title{
Skoolwoordeboeke vir huistaalleerders van Afrikaans
}

\author{
Sven Tarp, Departement Afrikaans en Nederlands, Universiteit van \\ Stellenbosch, Stellenbosch, Suid-Afrika en Sentrum vir Leksikografie, Aarhus \\ Sakeskool, Universiteit van Aarhus, Aarhus, Denemarke (st@asb.dk) \\ en \\ Rufus H. Gouws, Departement Afrikaans en Nederlands, Universiteit van \\ Stellenbosch, Stellenbosch, Suid-Afrika (rhg@sun.ac.za)
}

Opsomming: Skoolwoordeboeke vorm 'n uitgebreide tipologiese kategorie binne die versameling woordeboeksoorte. Die uiteenlopende verskeidenheid teikengebruikers van skoolwoordeboeke vereis egter ' $n$ duideliker tipologiese omskrywing en ' $n$ fyner onderverdeling in subkategorieë. Hierdie artikel fokus eerstens op sommige van die verskillende interpretasies van die term skoolwoordeboek en die onduidelikheid wat met die gebruik van hierdie term saamhang. 'n Onpresiese gebruik van die term lei daartoe dat voornemende gebruikers van skoolwoordeboeke nie weet wat om in 'n betrokke woordeboek te verwag en wie die beplande teikengebruikers daarvan is nie. Die leksikografiese funksies van skoolwoordeboeke word bespreek met die klem op Afrikaanse skoolwoordeboeke vir huistaalleerders. 'n Oorsig en kontekstualisering van hierdie woordeboeke word gevolg deur 'n bespreking van verskeie woordeboeke vir laerskool- en hoërskoolleerders. Aandag word gegee aan aspekte van die funksies, struktuur en inhoud asook aan positiewe en negatiewe kenmerke van die onderskeie woordeboeke. Dit blyk dat die ontwikkeling in die teoretiese leksikografie ' $n$ positiewe invloed op die samestelling van skoolwoordeboeke gehad het. Uiteindelik word 'n aantal aanbevelings gemaak vir die verbetering van toekomstige skoolwoordeboeke. Die belangrikheid van 'n ondubbelsinnige aanduiding van onder meer die teikengebruikers en die gebruikersituasie word benadruk. Die opname, aanbieding en bewerking van data moet met inagneming van die gebruikersprofiel geskied.

Sleutelwoorde: ADDISIONELE TAAL, GEBRUIKERSITUASIE, GRONDSLAGFASE, HOËRSKOOLLEERDERS, HUISTAAL, KOGNITIEWE FUNKSIE, LAERSKOOLLEERDERS, LEKSIKOGRAFIESE FUNKSIES, SKOOLWOORDEBOEK, TEIKENGEBRUIKER, TEKSPRODUKSIE, TEKSRESEPSIE, WOORDEBOEKTIPOLOGIE

Abstract: School Dictionaries for Home Language Learners of Afrikaans.
School dictionaries constitute an extended typological category within the collection of dictionary
types. The divergent variety of target users of school dictionaries however demands a clearer
typological description and a more precise division in subcategories. This article focuses firstly on
some of the different interpretations of the term school dictionary and the obscurity related to the use
of this term. An imprecise use of the term leads to a situation where potential users of school dic-
tionaries do not know what to expect in a specific dictionary and who the envisaged target users of
the dictionary are. The lexicographic functions of school dictionaries are discussed with the empha-
sis on Afrikaans school dictionaries for home language learners. An overview and contextualisa-
tion of these dictionaries are followed by a discussion of different dictionaries for primary and 
secondary school learners. Attention is drawn to aspects of the functions, structure and contents as well as positive and negative features of the different dictionaries. It becomes evident that the development in theoretical lexicography has had a positive influence on the compilation of school dictionaries. In conclusion a number of suggestions are made for the improvement of future school dictionaries. The importance of an unambiguous indication of among others the target users and the user situation is stressed. The inclusion, presentation and treatment of data must be done in accordance with the user profile.

Keywords: ADDITIONAL LANGUAGE, COGNITIVE FUNCTION, DICTIONARY TYPOLOGY, FOUNDATION PHASE, SECONDARY SCHOOL LEARNERS, HOME LANGUAGE, LEXICOGRAPHIC FUNCTION, PRIMARY SCHOOL LEARNERS, SCHOOL DICTIONARY, TARGET USER, TEXT PRODUCTION, TEXT RECEPTION, USER SITUATION

\section{Inleiding}

In sy informatiewe boek oor pedagogiese leksikografie wys Welker (2008) daarop dat die grootste deel van die literatuur oor hierdie onderwerp gerig is op woordeboeke vir leerders van 'n niemoedertaal (vgl. Tarp 2010). Eintlik sou 'n mens die omgekeerde situasie te wagte wees, aangesien daar baie meer potensiële gebruikers van woordeboeke vir moedertaalsprekers is as woordeboeke vir leerders van vreemde tale. Hierdie verrassende feit sluit dit egter nie uit nie dat die algemene terminologiese verwarring en onsekerheid wat kenmerkend is van leksikografiese literatuur oor die algemeen, ook tot die sfeer van pedagogiese leksikografie vir moedertaalsprekers deurgedring het. Een van die gevolge van hierdie ontwikkeling is die omstredenheid van die begrip skoolwoordeboek. Sommige navorsers soos Hartmann en James (1998) en Welker (2008) beskou ' $n$ skoolwoordeboek as ' $n$ woordeboek wat ontwerp is om te help met die aanleer van 'n eerste of moedertaal, d.w.s. 'n huistaal. Hernandez (1989) en Lagane (1989) wat onderskeidelik net oor Spaanse en Franse skoolwoordeboeke praat, deel oënskynlik hierdie standpunt. Lombard (1990) rig sy bespreking ook volledig op eentalige skoolwoordeboeke terwyl Nyangone Assam (2006) en Mabika Mbokou (2006) fokus op skoolwoordeboeke in Gaboen met ' $n$ hibridiese struktuur: eentalig met ' $n$ tweetalige dimensie of tweetalig maar steeds gerig op huistaalsprekers, selfs van albei die behandelde tale. Daarteenoor bied ander navorsers 'n breër omskrywing in ooreenstemming met die praktyk in verskillende lande met onder meer tweetalige skoolwoordeboeke wat duidelik nie ontwerp is as ' $n$ hulpmiddel in die aanleer van 'n eerste taal nie, asook gespesialiseerde skoolwoordeboeke wat hulp moet verleen met die aanleer van 'n spesifieke vakgebied.

Om ook aan hierdie praktyk erkenning te gee, moet die gebruik van die term skoolwoordeboek uitgebrei word om te verwys na enige woordeboek wat saamgestel is om in die skool gebruik te word met die oog daarop om ondersteuning te bied aan die aanleer van ' $n$ huistaal, ' $n$ addisionele taal of ' $n$ vakgebied. In hierdie opsig is skoolwoordeboek dan 'n generiese term wat verskillende 
tipes woordeboeke insluit. Elkeen van hierdie tipes moet nader omskryf word om 'n presiese terminologie te verkry; ten minste vir gebruik in die teoretiese literatuur. Die begrip van 'n skoolwoordeboek sluit egter nie alle woordeboeke in wat op skool gebruik word nie maar slegs daardie woordeboeke wat ontwerp is vir daardie doel. In hierdie verband moet ' $n$ verdere onderskeid gemaak word tussen skoolwoordeboeke wat verkorte of gereduseerde weergawes van omvattender algemene woordeboeke is en die werklike skoolwoordeboeke wat van meet af aan as sodanig beplan is en daarom aangepas is by die skoolleerders se taalkundige, verstandelike, kulturele en ensiklopediese ontwikkeling.

Wanneer ons skoolwoordeboeke omskryf as woordeboeke wat ontwerp is om op skool gebruik te word, verwys ons na alle woordeboeke wat beplan is om skoolleerders te help vanaf die begin van hulle skoolloopbaan op die ouderdom van 5, 6 of 7 totdat hulle skool verlaat op die ouderdom van 16, 17 of 18 , na gelang van die betrokke land se onderwysstelsel. Hier word in ag geneem dat daar verwarring voorkom in die literatuur van die teoretiese leksikografie. Ter illustrasie: in sy artikel oor kinderwoordeboeke dui Hausmann (1990) aan dat daar geen duidelike skeidslyn tussen kinderwoordeboeke en skoolwoordeboeke bestaan nie en dat die titels dikwels nie die regte inhoud weerspieël nie. Vergelykbare kommentaar is te vinde in Hartmann en James (1998: 20) wat onder die lemma children's dictionary die volgende sê:

The transition between the dictionary for younger children and the school dictionary is fluid,

en in Bergenholtz et al. (1997: 214) wat onder die lemma pedagogical dictionary skryf:

Dit kan moeilik wees om 'n grens te stel tussen die mees elementêre skoolwoordeboeke (beginnerswoordeboeke) en kinderwoordeboeke.

Alhoewel Hausmann en Bergenholtz et al. die gebruikers van kinderwoordeboeke as tot en met die ouderdom van 10 beskou (terwyl ander navorsers dié ouderdom op 14 stel) definieer hulle, asook Hartmann en James, hierdie woordeboeke veral fenomenologies, dit is volgens die data wat in hulle ingesluit word. Indien die funksies van die onderskeie woordeboeke egter as vertrekpunt dien, word dit duidelik dat die meeste sogenaamde kinderwoordeboeke in feite beplan is om deur skoolkinders in die eerste grade van die laerskool gebruik te word en dat hulle spesifieke kenmerke die logiese resultaat van die skrywers se pogings is om dié woordeboeke aan te pas by die verstandelike en taalkundige ontwikkeling van hulle gebruikers. In hierdie verband moet die dikwels arbitrêre titels wat deur die uitgewers voorgestel word, nie beskou word as 'n relevante kriterium waarop 'n tipologie van woordeboeke gebaseer kan word nie; hulle werklike funksies is wel so 'n kriterium. Ons klassifiseer daarom die meeste sogenaamde kinderwoordeboeke as skoolwoordeboeke in- 
dien dit op een of ander manier duidelik is dat die hoofgebruikersgroep van so 'n woordeboek laerskoolleerders is.

Die begrip skoolwoordeboek verwys nie slegs na afsonderlik gedrukte woordeboeke nie maar ook na woordeboeke, dikwels glossaria genoem, wat geïntegreer is as agterteks in verskeie handboeke. Alhoewel hierdie tipe woordeboek feitlik volledig geïgnoreer word in die teoretiese literatuur, miskien met die uitsondering van De Sousa (1995: 143) wat woordeboeke wat terme definieer wat in sekere skoolhandboeke gebruik word, beskou as een van die twee basiese betekenisse van die term skoolwoordeboek, verdien hierdie glossaria tog baie meer teoretiese aandag omdat hulle belangrike leksikografiese werke is wat daagliks deur talle skoolleerders gebruik word. In hierdie artikel word daar voortaan net gewerk met afsonderlik gedrukte skoolwoordeboeke vir huistaalleerders van Afrikaans. 'n Bespreking en analise van handboekgeïntegreerde glossaria moet in 'n latere artikel aan die orde kom.

\section{Funksies van skoolwoordeboeke vir huistaalsprekers}

Skoolwoordeboeke vir huistaalleerders kan baie funksies hê. Dit geld met betrekking tot sowel die bepaalde gebruikersgroep wat vasgestel word deur die ouderdom, graad en die ooreenstemmende intellektuele, taalkundige, kulturele en ensiklopediese ontwikkeling van skoolleerders as die verskillende tipes leersituasies waar die kinders die woordeboek benodig of raadpleeg. Daar is eerstens twee kommunikatiewe situasies, dit is resepsie en produksie van geskrewe en gesproke tekste, waarin skoolwoordeboeke hulle gebruikers kan ondersteun. Tweedens is daar twee fundamentele kognitiewe situasies, dit is die leer van woordeskat en die leer van grammatika, waar kinders, dikwels saam met die opvoeder, die materiaal wat in woordeboeke voorsien word, gebruik om hierdie twee basiese komponente van taal te bestudeer. Aangesien 'n mens nie ' $n$ woord kan leer sonder om te weet waarna dit verwys nie, val woordeskatleer dikwels, veral by jong kinders, saam met die leer van ensiklopediese en kulturele sake. In hierdie verband kan skoolwoordeboeke kinders ook bystaan in 'n derde kognitiewe situasie, dit is om meer van die wêreld te leer en wêreldkennis te verwerf as 'n basis vir woordeskatleer. Hier vind 'n aktiewe wisselwerking tussen woordeskat- en wêreldkennis plaas. Woordeboeke wat spesifiek beplan is om te help met woordeskatleer bevat gewoonlik tematiese afdelings, dikwels met prentillustrasies, soms selfs as "lemmas", terwyl woordeboeke wat met grammatikaleer help spesiale afdelings bevat, in gedrukte woordeboeke meestal in die voorteksteafdeling, waar verbuiging, woordvorming, leestekengebruik en ander grammatiese aspekte op 'n sistematiese manier behandel word. In hierdie gevalle word die skoolwoordeboeke nie primêr as raadplegingsinstrumente gebruik nie maar eerder as minihandboeke wat, in plaas van "gewone" handboeke, afdeling vir afdeling bestudeer kan word. 
Afgesien van die gemelde twee kommunikatiewe en drie kognitiewe situasies wat almal van regstreekse belang vir die leer van taal is, kan skoolwoordeboeke in sommige lande ook hulp bied in 'n ander tipe kognitiewe situasie waar kinders iets van hulle taal moet weet. Dit is veral die geval wanneer die nasionale kurrikulum, byvoorbeeld in Suid-Afrika, vereis dat skoolleerders in spesifieke grade iets oor die herkoms en geskiedenis van hulle taal en sy woorde moet leer. Die gevolglike etimologiese funksie van sommige Afrikaanse skoolwoordeboeke hou dus nie verband met die leer van die taal nie maar net met die verwerwing van geleerde kennis oor die taal.

Ten slotte kan sommige skoolwoordeboeke, veral die sogenaamde kinderwoordeboeke, 'n bykomende onderliggende funksie hê, naamlik om skoolleerders te help om die gewoonte om woordeboeke te gebruik aan te leer en om woordeboekgebruiksvaardighede te ontwikkel (in Tarp 2008 word meer oor operasionele situasies gesê). In sy Spaanse leksikografiewoordeboek oordryf De Sousa (1995: 158) miskien hierdie funksie wanneer hy 'n kinderwoordeboek beskryf uitsluitlik as ' $n$ woordeboek wat spesiaal beplan is om kinders in te lei in die gebruik van hierdie tipe werk.

Opsommend kan gesê word dat skoolwoordeboeke vir huistaalleerders die volgende sewe kommunikatiewe, kognitiewe en operasionele funksies behoort te hê waarvan slegs vyf regstreeks verband hou met die leer van die huistaal/eerste taal:

Kommunikatiewe funksies regstreeks ter sake vir taalleer

(1) Om skoolleerders te help met teksresepsie (skriftelik of mondeling)

(2) Om skoolleerders te help met teksproduksie (skriftelik of mondeling)

Kognitiewe funksies regstreeks ter sake vir taalleer

(3) Om skoolleerders te help met die leer van grammatika

(4) Om skoolleerders te help met woordeskatleer

(5) Om skoolleerders te help om van die wêreld te leer

Kognitiewe funksies nie regstreeks ter sake vir taalleer nie

(6) Om skoolleerders te help om etimologie te leer

Operasionele funksie nie regstreeks ter sake vir taalleer nie

(7) Om skoolleerders te help met die ontwikkeling van woordeboekvaardighede

Dit is vanselfsprekend dat verskeie van hierdie funksies beperk is tot skoolleerders van ' $n$ sekere ouderdom en dat die individuele skoolwoordeboek, selfs al is dit van hoogstaande gehalte, nie daardie funksies hoef te vertoon wat nie ter sake is vir die ouderdom en graad van die beplande gebruikersgroep nie. 


\section{Afrikaanse skoolwoordeboeke: oorsig en kontekstualisering}

Een van die tipiese probleme in baie omgewings waar woordeboeke gebruik moet word, is dat gebruikers nie genoegsaam bewus is van die verskeidenheid woordeboeksoorte wat bestaan nie. Daar word te dikwels gewerk met die idee van "die woordeboek" in plaas van "' $n$ woordeboek" en dit lei daartoe dat een woordeboek gesien word as 'n bron waarin oplossings vir alle leksikografies verwante probleme gesoek moet word. Die skep van 'n woordeboekkultuur bring groter kennis en bewustheid van tipologiese verskeidenheid mee. 'n Woordeboekkultuur wat volgens Hausmann (1989) daartoe lei dat die gemeenskap by die leksikografie aanpas, is nie net ter sake vir bestaande en voornemende woordeboekgebruikers nie. Ook leksikograwe toon dikwels te weinig tekens van die invloed van 'n woordeboekkultuur. Dit blyk veral daaruit dat daar in die leksikografie met sy breë tipologiese verskeidenheid dikwels onduidelikheid bestaan oor die presiese aard en omvang van 'n bepaalde tipologiese kategorie en oor hoe woordeboeke wat tot so 'n kategorie behoort, inpas by die groter woordeboekversameling van 'n bepaalde taal. Hier gaan dit om sowel die teikengebruiker as die leksikograaf wat met dié onduidelikheid sukkel.

In die gesprek oor woordeboektipologie (vgl. onder meer Malkiel 1967, Zgusta 1971, Geeraerts 1984, Kromann et al. 1984, Gouws 1989, 2007) word dit duidelik gestel dat daar ' $n$ verskeidenheid woordeboektipes is en dat elke tipe 'n bepaalde opdrag het, op ' $n$ spesifieke tipe inligtingsoordrag gerig is en die data op 'n bepaalde manier moet verpak sodat die geïdentifiseerde teikengebruiker die inligting ten beste kan ontsluit. Dit word ook aanvaar dat woordeboeksoorte nie afgeslote kategorieë is nie maar dat daar oorvleueling tussen verskillende subtipes is. Die onderskeid is nie absoluut nie. In onlangse navorsing oor woordeboektipologie (vgl. Gouws 2007) word dit beklemtoon dat daar afgewyk moet word van 'n te rigiede tipologiese klassifikasie ten gunste van ' $n$ soepeler indeling van woordeboeke volgens gebruikersbehoeftes. So 'n pleidooi vir ' $n$ soepeler indeling impliseer nie ' $n$ minder duidelike aanduiding van die woordeboeksoort nie maar eerder 'n buigsamer benadering waar oorvleueling erken word en waar daar met andersoortige bepalende kenmerke eerder as suiwer linguistiese kriteria gewerk word. So 'n benadering moet egter waak teen die gebruik van te vae of te lomp tipologiese klassifikasies wat aan 'n voornemende gebruiker te min leiding gee oor wat hy/sy in die betrokke woordeboek kan verwag en wat aan die leksikograaf te veel geleentheid gee om op ' $n$ niespesifieke manier met die opname en bewerking van woorde om te gaan.

Die kategorie skoolwoordeboeke is juis ' $n$ voorbeeld van so ' $n$ tipologiese kategorie wat dikwels deur vaagheid en lompheid gekenmerk word. Aangesien skoolwoordeboeke met ' $n$ duidelik geïdentifiseerde maar onderling uiteenlopende teikengebruikersgroep werk, is dit belangrik om 'n meer presiese omskrywing van die gebruiker te bied eerder as om bloot te sê dat 'n bepaalde 
naslaanwerk 'n skoolwoordeboek is. Gegee die feit dat 'n leerder in Suid-Afrika se skoolloopbaan oor minstens 12 jaar strek en dat die taalbehoeftes van leerders uiteenlopend is, behoort dit duidelik te wees dat die tipologiese kategorie skoolwoordeboeke geensins homogeen is nie. 'n Belangrike onderskeid binne hierdie kategorie is dié tussen woordeboeke wat die algemene taal en dié wat gespesialiseerde taal as onderwerp het. Binne albei hierdie kategorieë kan daar ook 'n onderskeid gemaak word tussen eentalige en twee- of meertalige woordeboeke en daarnaas ook eentalige woordeboeke wat 'n tweetalige dimensie het. Laasgenoemde tipe kom veral voor wanneer 'n woordeboek wat primêr as eentalige woordeboek saamgestel is, ook bykomende inskrywings, tipieserwys vertaalekwivalente, in 'n tweede taal bevat. Binne elk van die genoemde kategorieë is onderverdelings aantoonbaar en dié verskillende subtipes kan veral gemotiveer word op grond van teikengebruikers en gebruikersbehoeftes. ' $n$ Primêre onderskeid is tussen woordeboeke vir huistaalsprekers en vir tweedeof addisioneletaalsprekers. Daarbenewens is die onderskeid tussen woordeboeke vir verskillende ouderdomme of grade in die skool ook van wesenlike belang. ' $n$ Bepalende tipologiese aspek wat in al hierdie subtipes ' $n$ rol behoort te speel, is die leksikografiese funksie van die betrokke woordeboek. Die verskillende tipes skoolwoordeboeke sal veral van mekaar verskil ten opsigte van 'n kognitiewe al dan 'n kommunikatiewe funksie en binne laasgenoemde groep sal tussen teksresepsie en teksproduksie onderskei word (vgl. Tarp 2000). Daarnaas moet 'n onderskeid tussen mono-, bi- en polifunksionele woordeboeke ook die tipologiese subverdeling binne die kategorie skoolwoordeboeke beïnvloed.

Woordeboekgebruikers moet besef dat een skoolwoordeboek nie die leksikografiese behoeftes van alle leerders kan bevredig nie en behoort daarom met groter omsigtigheid 'n woordeboekkeuse uit te oefen. Eweneens moet leksikograwe wat skoolwoordeboeke skryf, 'n subtipologiese sensitiwiteit aan die dag lê en 'n ondubbelsinnige aanduiding gee ten opsigte van die spesifieke gerigtheid van die woordeboek asook wie die geïdentifiseerde teikengebruikersgroep is. Dit mag nie aan die gebruiker oorgelaat word om self te moet besluit wie die teikengebruiker is nie. Ongelukkig laat te veel leksikograwe na om hierdie leiding in die titel, subtitel of elders in hulle woordeboek weer te gee. Te dikwels word dit nie eers eksplisiet gestel dat dit om 'n skoolwoordeboek gaan nie.

Waar woordeboeke wat vir skole saamgestel word, wel in byvoorbeeld die titel, subtitel of opdragomskrywing eksplisiet daarop dui dat die betrokke woordeboek vir gebruik in skole saamgestel is, word so 'n aanduiding te ongereeld vergesel van 'n identifisering van die spesifieke ouderdomsgroep of skoolgraad waarop die woordeboek gerig is. Binne die Afrikaanse en SuidAfrikaanse konteks word daar te dikwels nog te maklik met die onskerp klassifikasie "skoolwoordeboek" gewerk. Hierdie klassifikasie misken die feit dat geen enkele skoolwoordeboek geskik vir alle grade en ouderdomsgroepe kan 
wees nie. Veel groter sensitiwiteit moet aan die dag gelê word om te verseker dat die beplanning en samestelling van 'n woordeboek wat binne die breë kategorie van skoolwoordeboeke val, op die spesifieke behoeftes en naslaanvaardighede van ' $n$ veel duideliker omskrewe teikengebruikersgroep binne die versameling leerders gerig is. Hier is 'n blote verdeling tussen gebruik in hoër- en gebruik in laerskole ook nie bevredigend nie aangesien daar byvoorbeeld in die laerskool 'n te groot verskil in die behoeftes en vaardighede van grondslagfaseleerders en leerders in die senior intermediêre fases bestaan. 'n Vraag kan met reg ook gevra word of 'n enkele woordeboek vir gebruik in hoërskole regverdigbaar is aangesien die graad 8-leerder en die graad 12-leerder uiteenlopende behoeftes het. Ook hier moet die moontlikheid ondersoek word om tipologies te onderskei tussen ' $n$ woordeboek vir byvoorbeeld graad 8-10 en 'n ander vir graad 11-12.

In die beplanning van skoolwoordeboeke, veral in die Suid-Afrikaanse omgewing, moet daar ook deeglik rekening gehou word met die feit dat daar nie altyd ' $n$ voorspelbare een-tot-een-afparing bestaan tussen die skoolgraad en die huistaalsprekersvlak of die skoolgraad en die onderrigtaalvlak van 'n leerder nie. Tipieserwys is ' $n$ leerder van 11 miskien in graad 5 maar ' $n$ woordeboek wat gebruik moet word om hom/haar met teksproduksie en/of teksresepsie te help, moet miskien eerder op graad 4-vlak gerig wees. Die werklike lees- en verstaanvermoë van 'n leerder is dikwels gelykstaande aan wat tot ' $n$ graad of wat laer behoort. Wat vir die huistaalspreker van ' $n$ bepaalde skoolgraad ter sake is in ' $n$ gegewe woordeboek is nie onproblematies in ' $n$ meertalige omgewing waar al die tale nie dieselfde beregtiging as onderrigtale het nie. Daar moet naamlik onderskei word tussen woordeboeke vir onderrigtaal en woordeboeke vir huistaalonderrig aangesien die onderrigtaal nie noodwendig die huistaal van ' $n$ betrokke leerder is nie. ' $n$ Leerder kan dus in byvoorbeeld graad 6 wees maar die onderrigtaal is sy/haar tweede of derde taal wat egter as eerste taal deur die leerder gevolg moet word. Alhoewel so 'n leerder dan in graad 6 is, is die vlak van sy/haar kennis van die taal van onderrig wat ook in die betrokke skool as sy/haar eerste taal aangebied word, eerder gelykstaande aan dit wat minstens een vlak laer aangebied word. 'n Leerder in graad 8 sal dan byvoorbeeld veel meer baat by 'n woordeboek wat op graad 7, eerder as een wat op graad 8 gerig is. Dit word selfs vir taalgebruikers wie se huistaal hulle eerste taal en onderrigtaal is, bevestig deur bevindinge van Prinsloo en De Schryver (Op koms) dat gebruikers dikwels gemakliker is met 'n woordeboek wat op 'n vlak laer, eerder as een wat op hulle eie vlak gerig is.

In die Suid-Afrikaanse woordeboekmark sluit die kategorie skoolwoordeboeke ook ' $n$ verskeidenheid tweetalige woordeboeke in. In die geval van byvoorbeeld ' $n$ woordeboek met Afrikaans en Engels as behandelde taalpaar is dit miskien dikwels so dat die woordeboek (ook) op die Afrikaanssprekende leerder se behoeftes gerig is maar dan veral die behoeftes ten opsigte van Engels, dit is die tweede taal. In hierdie verband stel die Oxford Afrikaans- 
Engels/English-Afrikaans Skoolwoordeboek/School Dictionary dit heel duidelik op sy agterblad dat die woordeboek ontwerp is "om leerders doeltreffend en bedrewe in hulle addisionele taal te laat skryf en praat". So 'n woordeboek is dus nie gerig op die behoeftes van die huistaalspreker van Afrikaans ten opsigte van Afrikaans nie. Gevolglik val dit buite hierdie bespreking. 'n Tweetalige skoolwoordeboek wat vir baie lank 'n dominante rol in die skoolmark gehad het, is die Tweetalige skoolwoordeboek Afrikaans-Engels/Engels-Afrikaans. In die voorwoord van hierdie woordeboek word die teikengebruikers bloot as "leerlinge van die middelbare skool" aangedui. Daar is geen vermelding van die huistaal van die teikengebruikers nie. Dit word ook pertinent gestel dat hierdie woordeboek 'n verkorte weergawe is van die Tweetalige woordeboek. Vanuit ' $n$ hedendaagse leksikografiese perspektief is dit 'n veroordelende uitspraak want die leksikograaf gee daardeur te kenne dat die woordeboek nie as 'n skoolwoordeboek gekonseptualiseer is nie maar 'n blote verkorting van 'n woordeboek wat ' $n$ heeltemal ander gebruikerstipe en daarom ' $n$ andersoortige dataversameling en data-aanbod het. ' $n$ Skoolwoordeboek mag naamlik nie net 'n verkorte weergawe van 'n omvattender woordeboek wees nie. As tipologiese kategorie in eie reg moet 'n skoolwoordeboek van meet af as sodanig beplan en saamgestel word. Een van die eerste tweetalige woordeboeke met Afrikaans en Engels, dié van Kritzinger et al. (1921), is as 'n skoolwoordeboek beplan en later aangepas en uitgebrei tot 'n omvattender woordeboek. Die moontlike sukses van die uitbreiding tot ' $n$ ander tipologiese kategorie word nie hier bespreek nie. Ter sake is dat die woordeboek as skoolwoordeboek beplan en saamgestel is. Tweetalige woordeboeke is egter nie tipieserwys in hulle bewerking daarop gerig om aan die gebruikers ' $n$ uitbreiding van kennis oor hulle huistaal te bied nie.

As woordeboek gerig op leerders binne die Suid-Afrikaanse taalomgewing kan die leksikograaf nie 'n gelyke kennis van die twee behandelde tale by 'n teikengebruiker verwag nie. Vir die onthalwe van die Afrikaanssprekende wat die afdeling Afrikaans-Engels gebruik om 'n Engelse vertaalekwivalent vir 'n Afrikaanse vorm te kry, sou verwag kon word dat leiding gegee moet word om die keuse van die korrekte vertaalekwivalent te verseker. Die leiding word op 'n uiters inkonsekwente manier gegee en ontbreek dikwels feitlik geheel en al. Vergelyk byvoorbeeld die artikel van die lemma stamp as werkwoord (in Tweetalige skoolwoordeboek) wat die volgende bewerking in die semantiese kommentaar bied:

knock, pound, hit, give a blow; stamp; pound, crush; bruise; bump, jolt; thud; pitch (of ship); ram (into a gun, throat); fyn-, pound, crush, bray; ...

Om van ' $n$ leerder te verwag om die juiste vertaalekwivalent vir ' $n$ bepaalde optrede van stamp te kies, is uiters onbillik. 
Ander tweetalige woordeboeke met Afrikaans en Engels, bv. dié van Pharos, stel dit glad nie duidelik op watter sprekersgroep die woordeboek gerig is nie. Daar kan egter aanvaar word dat die bewerking nie aan Afrikaanse huistaalsprekers 'n beter kennis van Afrikaans gaan gee nie. Dus val tweetalige skoolwoordeboeke buite die bestek van hierdie artikel.

Die fokus in hierdie artikel is op eentalige Afrikaanse woordeboeke en wel op dié wat primêr op gebruik deur huistaalsprekers gerig is. Ook in hierdie kategorie woordeboeke word daar meestal nie duidelik genoeg aangedui of die woordeboek op huistaalsprekers al dan nie gerig is nie. Die werklike gebruiksituasie van 'n bepaalde woordeboek loop ook nie noodwendig parallel met dit wat deur die leksikograaf beplan is nie. 'n Woordeboek soos die Afrikaanse Nuwe woordeboek sonder grense is saamgestel vir addisioneletaalleerders van Afrikaans in grade 4 tot 6 . Volgens die voorwoord is dié woordeboek geskik vir sowel eerste- as tweede-addisioneletaalsprekers. Die werklikheid van die gebruiksituasie lewer egter bewys dat hierdie woordeboek ook dikwels in skole vir huistaalsprekers gebruik word. Dit is nogmaals 'n bevestiging van die reeds genoemde uitspraak van Prinsloo en De Schryver (Op koms) dat gebruikers dikwels 'n woordeboek van 'n laer vlak verkies.

In sommige woordeboeke wat nie in die titel, subtitel, voorwoord of in 'n ander buiteteks 'n aanduiding bied van die teikengebruikers nie, is die aard, omvang en daarstelling van die data ook sodanig dat 'n mens nie kan aflei op watter gebruikersgroep die woordeboek gerig is nie. Uit die titel van 'n woordeboek soos Educum-uitgewers se Junior verklarende woordeboek kan 'n mens aflei dat dit waarskynlik op laerskoolleerders gerig is maar daar is geen aanduiding of dit gerig is op huistaalsprekers al dan nie. Hierdie gebrekkige leiding en veral die gebrekkige beplanning onderliggend daaraan dra by tot die mindere sukses van so 'n woordeboek as 'n praktiese gebruiksinstrument in die hand van die leerder en as ' $n$ taalleerinstrument in die hand van die leerkrag.

Vervolgens word aandag gegee aan verskillende Afrikaanse woordeboeke vir huistaalsprekers. 'n Kritiese bespreking word gevolg deur aanbevelings wat tot die verbetering van hierdie breë woordeboekkategorie kan lei.

\section{Afrikaanse skoolwoordeboeke}

In die hieropvolgende afdelings word vyf woordeboeke wat gedeeltelik of ten volle ontwerp is vir gebruik in Suid-Afrikaanse skole as hulpmiddel vir huistaalleerders van Afrikaans aan die orde gestel. In sommige van hierdie woordeboeke word eksplisiet gemeld op watter grade hulle gerig is terwyl ander glad nie daarna verwys nie. Aangesien die woordeboeke nie almal op dieselfde graadgroep gerig is nie, word hulle in twee groepe verdeel wat afsonderlik bespreek word, te wete dié wat ontwerp is vir sommige grade in die laerskool en dié waarna daar in hierdie artikel op grond van bepaalde kenmerke verwys word as hoërskoolwoordeboeke, alhoewel die woordeboeke self geen aanduiding gee van hulle teikengroep nie. 


\subsection{Woordeboeke vir laerskoolgebruik}

Die eerste woordeboek wat hier bespreek word, is Ben Conradie se Verklarende Afrikaanse woordeboek vir laerskole wat in 1967 verskyn het en een van die vroeë Afrikaanse woordeboeke is wat spesifiek vir skoolgebruik ontwerp is. Afgesien van die verwysing in die titel dat die woordeboek vir laerskole saamgestel is, word daar geen verdere inligting voorsien oor sy funksies of die grade waarvoor dit beplan is nie. Die kort inleidingsteks gee slegs te kenne dat dit in ooreenstemming met die jongste uitgawe van die Afrikaanse Woordelys en Spelreëls gemaak is. Die sentrale teks van die woordeboek beslaan 207 bladsye met ongeveer 12000 lemmas, asook 'n agtertekstelys van 3 bladsye wat die algemeenste afkortings bevat. Die woordeboek het 'n tradisionele uitleg wat lyk soos die verstekwoordeboek vir volwassenes van daardie tyd. Die artikels bevat ' $n$ lemma met ' $n$ aanduiding van hoofklem en verbuiging, gevolg deur kort definisies wat soms deur voorbeeldsinne ondersteun word. In sommige gevalle, maar taamlik selde, word die woordsoort ook aangedui:

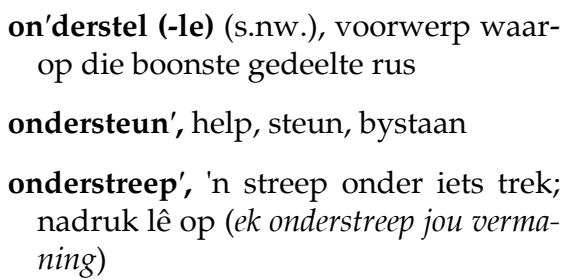

Die dekades na die verskyning van hierdie woordeboek het min nuwe skoolwoordeboeke met ' $n$ werklik vernuwende aanslag vir Afrikaanse huistaalleerders in die laerskool gelewer. 'n Volgende belangrike bydrae was die Shuters Junior woordeboek wat in 2001 verskyn het om aan Afrikaanse skoolleerders 'n leksikografiese produk te gee wat sterker gerig was op hulle spesifieke vlak en behoeftes. Soos sy voorganger verstrek hierdie woordeboek min inligting oor homself en sy funksies. Die woord junior in die titel suggereer wel dat die woordeboek vir laerskoolleerders saamgestel is, en op die agterste buiteblad staan daar die woordeboek is "geskryf vir kinders vanaf 8 jaar oud" - dus waarskynlik vir leerders vanaf graad 2 of 3 en ouer. Die kort teks op die agterste buiteblad dui ook aan dat die woordeboek 3300 woorde en 450 illustrasies bevat. Dit is "gebaseer op navorsing oor die woorde wat jong lesers die meeste benodig" en die "definisies gebruik hoëfrekwensiewoorde". Hiermee het die Shuters Junior woordeboek belangrike vooruitgang gemaak ten opsigte van 'n leksikografiese produk wat aangepas is by die spesifieke behoeftes van laerskoolleerders. Die aantal lemmas is omtrent een kwart van dit wat in die Verklarende Afrikaanse woordeboek vir laerskole aangebied word maar die lemmakeuse is gebaseer op wetenskaplike kriteria en navorsing oor die woordeskat wat gebruik en benodig word vir die teikengebruikersgroep. Daarbenewens is daar 
nuwe beginsels ingevoer om die definisies verstaanbaarder te maak en hulle by die leerders se taalkundige en verstandelike ontwikkeling te laat aanpas.

Afgesien van die sentrale teks met sy hooflemmalys bevat die woordeboek ook 'n klein prentjietrajek in die agtertekstegedeelte met ses tematies georganiseerde afdelings (Sport en ontspanning, Vervoer, Op die strand, Wonings, Skool en By die supermark) waar gepaste woorde by die onderskeie prentillustrasies gevoeg is. Dit verteenwoordig 'n vernuwing, maar die werklike waarde kan bevraagteken word omdat dit slegs ses afdelings bevat - alhoewel daar in hierdie afdelings meer as 200 woorde met prentjies geillustreer word. In vergelyking met die Verklarende Afrikaanse woordeboek vir laerskole, is die uitleg van die hooflemmalys ook 'n aansienlike verbetering. Hierdie afdeling beslaan 208 bladsye, amper dieselfde aantal as in die Verklarende Afrikaanse woordeboek vir laerskole, maar aangesien die nuwe woordeboek slegs omtrent 25 persent van die ouer woordeboek se aantal lemmas bevat, laat dit ruimte vir die gebruik van 'n groter en leesbaarder lettertipe asook vir meer ruimte tussen die artikels. Dit verhoog die toegang tot en leesbaarheid van die artikels. Daarbenewens word die letters van die alfabet op elke bladsy in vertikale rooi letters aangedui. Dit maak dit vir leerders makliker om die woorde te vind en help hulle ook met die bemeestering van die alfabet. Die artikels bestaan uit ' $n$ lemma (in vet rooi letters), 'n kort definisie en, in omtrent 25 persent van die gevalle, ' $n$ voorbeeldsin wat die gebruik van die woord illustreer en die definisie ondersteun. Die artikels gee nie woordsoortaanduiding nie en verbuiging word slegs in 'n redelik beperkte aantal gevalle verstrek waar daar ortografiese of ander probleme ondervind kan word. In die geval van polisemiese lemmas word die verskillende betekenisonderskeidinge deur syfers aangedui:

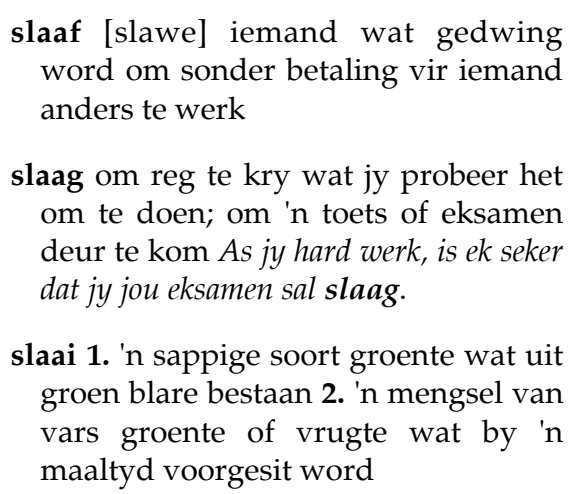

Die derde woordeboek wat hier bespreek word, is Maskew Miller Longman se Grondslagfasewoordeboek Afrikaans/English wat in 2010 verskyn het. Dit word duidelik gestel hierdie "woordeboek is geskik vir leerders in Graad 1 tot 4 en dek al die relevante assesseringstandaarde wat in die kurrikulum gespesifiseer word". Anders as in die geval van die voorafgaande twee woordeboeke gee 
hierdie woordeboek duidelik leiding (p. iv) oor sy teikengebruikersgroep en sy funksies:

Hierdie woordeboek sal jou help om:

- praat-, lees- en skryfvaardighede in jou huistaal [Afrikaans] te ontwikkel

- Engels as Addisionele Taal te verstaan en te gebruik

- Afrikaans as Addisionele Taal aan te leer en te gebruik.

Ondanks hierdie inligting, asook die reeds vermelde verwysing na Engels in die titel, laat die data wat in hierdie woordeboek aangebied word, min twyfel dat dit sy hoofdoel is om Afrikaanssprekende skoolleerders te help met die ontwikkeling van hulle huistaal. Afgesien van die inhoudsopgawe, 'n baie didakties hulpvaardige gebruikersgids en 'n oop bladsy met slegs die alfabetletters op, waarop leerders hulle eie eenbladsywoordeboek kan maak, bestaan Grondslagfasewoordeboek uit:

- $\quad$ 'n 26-bladsy-afdeling, die sogenaamde "prentewoordeboek", met 18 tematiese trajekte wat ongeveer 290 van die ongeveer 700 woorde bevat wat in die woordeboek behandel word;

- die hooflemmalys (65 bladsye) waar al die bladsye 'n vertikale alfabet het en waar al die artikels klein illustrasieprente bevat; in die meeste gevalle met verwysing na die trajekte van die prentewoordeboek waar die prente in hulle "natuurlike" tematiese omgewing gevind kan word;

- twee tweetalige woordelyste, Afrikaans-Engels en Engels-Afrikaans, met kruisverwysings na die bladsye in die hooflemmalys waar die betrokke woord behandel word.

Die artikels in die sentrale teks bevat, naas die lemmas en prentillustrasies, verbuigings, Engelse ekwivalente, definisies, voorbeeldsinne in sowel Afrikaans as Engels en, waar beskikbaar, Afrikaanse sinonieme en antonieme. In sommige gevalle is daar ook tekskassies wat aan die lemma geadresseer is met opmerkings wat "meer inligting oor 'n word en hoe om dit te gebruik" bevat. Die bladsy- en artikeluitleg met die benutting van 'n groot lettertipe en meer as genoeg ruimte tussen die artikels blyk goed aangepas te wees vir die geïdentifiseerde teikengroep. Hier volg drie artikels, maar sonder die prentillustrasies:

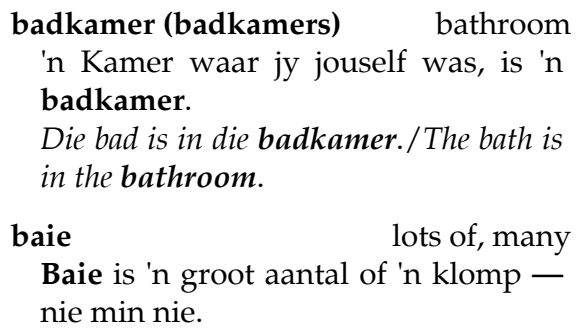


Daar is baie voëls in die boom./There are lots of birds in the tree.

Daar is baie bome in die park./There are many trees in the park.

TEENOOR: $\min$

bak (bakke)

dish

Iets waarin jy kos sit, is 'n bak.

Ons eet pap uit die bak. / We eat por-

ridge from this dish.

Soos reeds genoem, lyk dit of die Grondslagfasewoordeboek goed aangepas is vir skoolleerders van graad 1-4. Die konsekwente gebruik van illustrasieprente en veral ook die tematiese prentwoordeboekafdeling maak dit moontlik om op verskillende maniere toegang tot die data in hierdie woordeboek te kry, selfs wanneer die gebruikers nog besig is om die alfabet te bemeester. Die gebruik van definisies in natuurlike taal wat die woord wat gedefinieer word, insluit, maak dit makliker vir kinders om die betekenis te verstaan. Ongelukkig is daar verskeie gevalle waar die definisies woorde bevat wat nie as lemmas opgeneem is nie en wat moeilik verstaanbaar vir skoolleerders kan wees. Die woord familie word soos volg verklaar:

'n Familie is 'n groot groep mense wat verwant is aan mekaar.

Nóg mekaar nóg verwant (wat moeiliker verstaanbaar vir grondslagfaseleerders kan wees as familie) is as lemmas opgeneem. Nog 'n voorbeeld is in die tekskassie met die lemma lank as adres waar daar staan:

NOTA: Kyk mooi hoe verander lank wanneer ons dit voor 'n selfstandige naamwoord gebruik ...

Geeneen van die woorde verander, wanneer, selfstandig en naamwoord word in die woordeboek verklaar nie en vir die woord mooi word slegs ' $n$ ander betekenisonderskeiding verstrek. Indien hierdie tipe fout reggestel word, sal die Grondslagfasewoordeboek nog oortuigender wees en 'n groot stap vorentoe in vergelyking met ander woordeboeke vir laerskoolleerders beteken, veral met betrekking tot die natuurliketaaldefinisies, funksionele uitleg, groot tematiese prentewoordeboekafdeling en die verskeidenheid toegangsroetes vir skoolleerders met verskillende tipes behoeftes en vlakke van taalkundige en verstandelike ontwikkeling. Daarbenewens het hierdie woordeboek dalk selfs twee bykomende funksies wat nie genoem word nie, naamlik om regstreeks te help met woordeskatuitbreiding deur middel van die tematiese prentewoordeboekafdeling en om skoolleerders in te lei in woordeboekgebruik. 


\subsection{Woordeboeke vir die hoërskool}

In die Afrikaanse leksikografie het 'n woordeboek vir huistaalleerders van Afrikaans op hoërskoolvlak lank ontbreek. 'n Vernuwende bydrae in hierdie verband was die verskyning van F.F. Odendal se Kernwoordeboek in 2000. Alhoewel hierdie woordeboek geen aanduiding gee van sy teikengebruikersgroep nie, plaas persoonlike opmerkings deur die skrywer dit in die kategorie van ' $n$ skoolwoordeboek en uit die inhoud kan afgelei word dat dit primêr op hoërskoolleerders gerig is. In die "Voorwoord" sê die skrywer dat die woordeboek beplan is as 'n "verklarende woordeboek", en hy benadruk:

Die strewe was om die kernwoordeskat van Afrikaans te verklaar.

In hierdie opsig is die hoof verklaarde funksie van hierdie woordeboek om gebruikers te help met teksresepsie. Dit is egter nie heeltemal duidelik of dit ook bedoel is om die gebruiker met teksproduksie te help nie, alhoewel Odendal in die voorwoord skryf:

Daar is verder vryelik van voorbeeldsinne gebruik gemaak want dit is ten slotte wat die gebruiker van 'n woordeboek wil weet: Hoe kan ek die woord werklik gebruik noudat ek weet wat sy betekenis is?

'n Vinnige berekening toon dat die Kernwoordeboek ongeveer 15000 artikels bevat wat op elke bladsy in drie kolomme gerangskik is. Hierdie rankskikking gee aan die woordeboek ' $n$ baie kompakte voorkoms wat ongetwyfeld toegang tot die verlangde data bemoeilik. Die artikels bestaan uit 'n lemma (met aanduiding van lettergreepverdeling, hoofklem, woordsoort, verbuiging en verkleiningsvorm) gevolg deur 'n definisie en voorbeeldsinne. Sowel die definisie as die voorbeeldsinne sluit die woord in wat deur die lemma verteenwoordig word. Aan die einde van sommige artikels is daar ook vaste uitdrukkings ("idiome, spreekwoorde, gesegdes, ens.") en relevante kruisverwysings na ander artikels. In die geval van polisemiese lemmas word die verskillende polisemiese onderskeidinge elk deur ' $n$ syfer as polisemiemerker voorafgegaan. Aan sommige artikels is daar ook ' $\mathrm{n}$ lemmanis geheg met onverklaarde samestellings en afleidings:

frus-tra'sie s.nw. (frustrasies; frustrasietjie)

'n Frustrasie is iets wat ' $\mathrm{n}$ mens verhinder om te bereik wat jy wil doen: Klein frustrasies oorkom. Haar negatiewe houding was 'n groot frustrasie.

frustreer'.

fuif $w w$. (gefuif)

As 'n mens fuif, neem jy deel aan 'n jolige eet-en-drink-party: Tot die oggend 
vroeg fuif.

fuif'party. fui'wer(y).

fun'geer' $w w$. (gefungeer)

As 'n mens fungeer, neem jy waar in 'n posisie, verrig jy die diens of werksaamheid van iemand: As skoolhoof fungeer vir een kwartaal. Die dokter fungeer sommer ook as veearts.

funk'sie s.nw. (funksies)

1 Die taak, werk wat iemand of iets moet verrig, is hulle funksie: ' $n \mathrm{Be}$ langrike funksie binne die maatskappy he. Die funksie van die hart is om die bloed in omloop te hou. Die nuwe stuk masjinerie verrig sy funksie uitstekend. 2 'n Funksie is 'n sosiale, feestelike geleentheid: Die rugbyklub se jaarlikse funksie.

Die voorafgaande artikels bevat ook data, byvoorbeeld lettergreepverdeling, hoofklem, verkleiningsvorme, afleidings, ens. wat die gebruikers nie met teksresepsie nie maar wel met teksproduksie ondersteun. Indien die woordeboek regtig beplan is om skoolleerders met teksproduksie te help, sou 'n mens verwag het om hierdie bykomende data te vind maar veral ook data met betrekking tot sintaktiese kenmerke, kollokasies, sinonieme en antonieme. In hierdie opsig word daar slegs gedeeltelik voorsien in die teksproduksiefunksie. Maar dit is sonder meer duidelik dat die bogenoemde artikels wel hulp verleen met teksresepsie. Dit is ongetwyfeld so dat die samesteller deeglik nagedink het oor die beste manier waarop die definisies aangebied moet word. Hy skryf soos volg daaroor in die voorwoord:

Die metode wat nog slegs deur enkele moderne woordeboeke gebruik word, is toegepas, naamlik om die definisie in 'n volsin te gee waarin die hoofwoord self voorkom. Daardeur lees die definisie nie net makliker nie, en is dus nie net makliker verstaanbaar nie, maar die hoofwoord word onmiddellik gegee in 'n verband waarin dit in gewone Afrikaans gebruik word.

Ondanks hierdie tersaaklike stelling moet 'n mens dit tog wel oorweeg om na te gaan of al die definisies ewe suksesvol aangepas is by die taalkundige, verstandelike en kulturele vlak van die teikengroep en of, selfs deur dieselfde definiëringsbeginsels toe te pas, die definisies in 'n makliker styl geskryf kon gewees het, gebaseer op 'n beperkte definiëringswoordeskat. Eweneens kan ook gevra word of die woordeboek werklik die kernwoorde bevat wat hoërskoolleerders nodig het en of ander beginsels gebruik moes gewees het in die lemmakeuse om die lemmalys aan te pas by die woorde waarmee die leerders op skool te doen kry en wat hulle veronderstel is om te beheers. 
Die tweede woordeboek wat in hierdie afdeling bespreek word, is die HAT Afrikaanse skoolwoordeboek wat in 2009 gepubliseer is. Alhoewel hierdie woordeboek 'n onafhanklike publikasie in eie reg is, is dit baie aan die Kernwoordeboek as voorganger verskuldig. Hierdie erkenning word duidelik in die voorwoord deur die redakteur, Jana Luther, gegee:

Benewens die redaksionele span is ek groot erkentlikheid verskuldig aan prof. F.F. Odendal, wie se Kernwoordeboek van 2000 as basis vir die nuwe woordeboek gebruik is. Sonder dié stewige grondslag waarop ons kon voortbou, sou die publikasie van hierdie woordeboek vanjaar onmoontlik gewees het.

Die HAT Afrikaanse skoolwoordeboek toon baie verbeteringe ten opsigte van sy voorganger maar ook enkele terugwaartse treë. Een aspek waar die status quo gehandhaaf is, is die vlak van die inligting. Behalwe deur te sê dat dit ' $n$ skoolwoordeboek is wat gebruik moet word deur "Afrikaans Huistaal- en Afrikaans Eerste Addisionele Taalleerders" en "elke gebruiker van Afrikaans, nie net leerders nie", word daar niks gesê oor die grade van die teikengebruikers of die funksies van die woordeboek nie. Uit die inhoud wat hierna bespreek word, blyk dit dat hierdie woordeboek primêr vir hoërskoolleerders ontwerp is en nie ewe suksesvol deur laerskoolleerders gebruik sal kan word nie.

Afgesien van die voorwoord en die sentrale teks met die hooflemmalys bevat die HAT Afrikaanse skoolwoordeboek 'n kort sleutel tot die woordeboek asook 'n lys redaksionele afkortings, aangebied in die voorteksteafdeling, en, in die agterteksteafdeling, 'n afkortingslys en 'n lys "belangrike terme vir Afrikaans Huistaal en Afrikaans Eerste Addisionele Taal" - 'n bondige geïntegreerde woordeboekie in eie reg. Op die binnekant van die voorste buiteblad is 'n kort lysie intensiewe vorme en op die binnekant van die agterste buiteblad 'n lys vergelykings. Aangesien die gebruikersgids niks oor hierdie twee tekste sê nie, is dit moeilik om die rede vir hulle opname te bepaal.

Die aanbod in die sentrale teks is baie komplekser as dié van enige van die reeds bespreekte woordeboeke. Volgens die inligting op die agterste buiteblad bevat hierdie woordeboek 30000 woorde en 300 illustrasies maar volgens 'n vinnige berekening lyk dit eerder na 15000 artikels. Dit is nie duidelik hoe daar by 30000 uitgekom is nie, behalwe as afgeleide vorme wat as sublemmas opgeneem is, ook daarby ingesluit is. Die artikels bestaan telkens uit 'n lemma met 'n aanduiding van hoofklem, lettergreepverdeling, verbuiging, verkleiningsvorm en 'n definisie wat meestal deur ' $n$ voorbeeldsin ondersteun word. Anders as in die Kernwoordeboek word deeltjiewerkwoorde in hulle sintetiese en analitiese vorm aangebied. Dit is ' $n$ welkome toevoeging. Soms verskaf die artikels ook data oor sintaktiese kenmerke, idiomatiese uitdrukkings, spreekwoorde, sinonieme, antonieme en etimologie. Partykeer word 'n artikel gevolg deur ' $n$ tekskassie met inligting oor woorde met 'n soortgelyke betekenis (tesouruskassies), gebruik, spelling en skryfwyse: 
aan $\cdot$ leg s.nw. [ te of gings of ginge of aanlêe] 1 'n plek wat vir 'n spesiale doel ontwerp is: ' $n$ aanleg om olie uit steenkool te verkry. 2 die talent wat iemand het: 'n aanleg vir kuns/ musiek/wiskunde hê.

aan'lei·ding s.nw. [ s of $\sim \mathbf{e}]$ die aanleiding tot iets die rede waarom iets gebeur: die aanleiding tot 'n oorlog/ rusie/opstand. | na aanleiding van ... $\mathrm{Na}$ aanleiding van $u$ vraag/brief antwoord ek graag soos volg.

aan'lok ww. [lok aan; het aangelok] iem./iets aanlok iets aangenaams sê/ voorstel/wys/aanbied om iemand/ iets na jou toe of na 'n plek te laat kom: kliënte aanlok met advertensies 。 Bye word deur die geur van blomme aangelok.

- aan·lok·lik $b . n w ., b w .[\sim \mathbf{e}$; aanlokliker, die aanloklikste] baie aantreklik of verleidelik; wat iemand/iets aantrek: ' $n$ aanloklike aanbod/prys $\circ$ ' $n$ aanloklike kampeerplek.

\section{TESOURUS}

aantreklik ' $n$ aantreklike werksomgewing. begeerlik ' $n$ begeerlike skildery.

onweerstaanbaar onweerstaanbare geure. verleidelik verleidelike perskes.

aan'loop o ww. [loop aan; het aangeloop]

1 verder loop: Rus julle maar ' $n$ bietjie; ek loop verder aan. ${ }^{\circ}$ As jy 'n entjie aanloop, sal jy die winkel op die hoek kry. 2 vinniger loop: Ons moet aanloop, anders is ons laat.

口 s.nw. [aanlope] 1 'n klomp mense wat iewers aankom: Daar is altyd ' $n$ hele aanloop van vriende by die meisie se huis. 2 die inleiding tot iets: Die aanloop tot sy toespraak was maar vervelig. 3 die afstand/beweging voordat ' $\mathrm{n}$ handeling uitgevoer word: 'n bouler/hoogspringer se aanloop. 
- aan'loop·baan s.nw. [aanloopbane] die strook waarvandaan vliegtuie opstyg en waarop hulle land.

Soos uit hierdie voorbeeld blyk, bevat die HAT Afrikaanse skoolwoordeboek die meeste data wat nodig is om gebruikers met sowel teksresepsie as teksproduksie te help. Dit is beduidende vordering vanaf die Kernwoordeboek waarop dit gedeeltelik gebaseer is. Die aanbod is egter nie oral op die beste moontlike en mees gebruikersvriendelike manier nie. Dit kan egter in 'n tweede uitgawe van die woordeboek verbeter word. In die hieropvolgende paragrawe word vyf van die belangrikste probleme in hierdie woordeboek bespreek.

Die eerste probleem blyk uit die tradisionele definisiemetode met sy bondige betekenisverklarings wat die Kernwoordeboek se metode om natuurliketaaldefinisies te gebruik, vervang het. Onses insiens bied hierdie verandering nie die beste oplossing vir hoërskoolleerders nie. Die definiëringsmetodes wat deur sy voorganger ontwikkel is, moes liefs in hierdie woordeboek gehandhaaf en selfs verder ontwikkel gewees het.

'n Tweede probleem wat ons ook as 'n terugwaartse stap in vergelyking met die Kernwoordeboek beskou, is die gereelde aanduiding van twee of meer verbuigings- of spellingvariante, soos blyk uit die bogenoemde artikels van die lemmas aanleg en aanleiding. Hierdeur word die variasie wat deur die Taalkommissie in sy Afrikaanse woordelys en spelreëls erken word, wel weerspieël maar die vraag is of die manier waarop dit hier aangebied word vir die gebruiker die beste moontlike hulp verleen. Gebruikers is onseker watter een om te kies wat die raadplegingstyd verleng. Hulle kies dan meestal op 'n lukraak manier en die keuse is dikwels ten gunste van 'n minder frekwente of minder bekende vorm. In 'n woordeboek vir volwassenes sou hierdie deskriptiewe prosedure beter kon werk maar in 'n skoolwoordeboek behoort 'n proskriptiewe metode eerder gevolg te word met die leksikograaf wat slegs een variant gee of meerdere variante aanbied maar een bepaalde vorm aanbeveel (vgl. Tarp en Gouws 2008).

Die derde probleem spruit uit die kompaktheid van die woordeboekartikels. Op elke bladsy is die deeltrajekte in twee kolomme gerangskik. Dit is ' $n$ verbetering op die drie kolomme in die Kernwoordeboek maar as gevolg van al die data in elke artikel het die artikels 'n uiters verdigte en kompakte voorkoms wat kitstoegang tot die data kan benadeel en ook die leesbaarheid en daarmee die werklike bruikbaarheid van die woordeboek in gedrang kan bring. Verskeie aspekte dra tot hierdie probleem by, byvoorbeeld dat afgeleide vorme wat as verklaarde vorme opgeneem word, as sublemmas van die artikel van die basisvorm, die hooflemma, behandel word, soos blyk uit die artikels aanlok en aanloop waar aanloklik en aanloopbaan onderskeidelik as verklaarde sublemmas gegee word. Sowel aanloklik as aanloopbaan kon eerder as onafhanklike hooflemmas opgeneem gewees het aangesien elk van hulle die adres is van ' $n$ 
verskeidenheid aanduiders wat die verstekdataoordrag van 'n artikel bewerkstellig. Die tradisie wat in talle woordeboeke vir volwassenes gevolg word, naamlik om grammatiese homonieme in dieselfde artikel te plaas, word ook hier gevolg. Die vraag kan gevra word of dit die aangewese aanbiedingswyse vir 'n skoolwoordeboek is. Indien sulke vorme in verskillende artikels sou optree, kon dit toegang tot hierdie vorme vergemaklik het en die artikels minder kompak gemaak het. Alhoewel redaksionele en ander afkortings in onderskeie buitetekste in die voor- en agterteksteafdelings aangebied word, dra die veelvuldige afkortinggebruik in die woordeboekartikels wat die gebruiker nie altyd met die ooreenstemmende volvorme in verband kan bring nie, by tot die kompaktheid van die artikels. Die gebrek aan 'n gebruikersvriendelike artikelinterne soekveldstruktuur en mikroargitektuur (vgl. Bergenholtz, Tarp en Wiegand 1999) maak dit moeilik om vinnig te kan onderskei tussen die aanduiders wat die verskillende datatipes oordra. Die feit dat die verklaring van elke nuwe betekenisonderskeiding nie soos in die Kernwoordeboek op 'n nuwe reël begin nie, verhoog ook die kompaktheid van die artikels. Met 'n gebruikersvriendeliker mikroargitektuur en soekveldstruktuur kon die artikel van die lemma aanloop soos volg gelyk het:

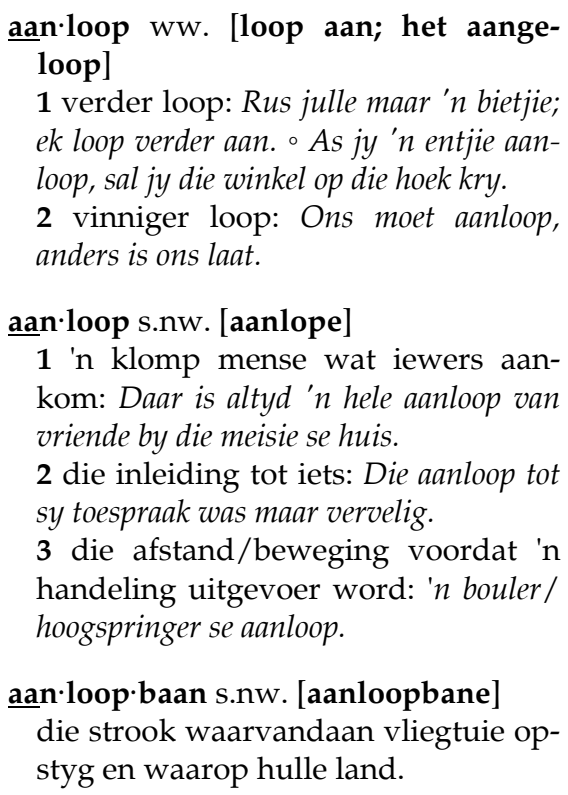

'n Vierde probleem is die hantering van homonieme in die HAT Afrikaanse skoolwoordeboek. Hulle word op dieselfde manier aangebied as in baie Afrikaanse en ander woordeboeke. Dit is egter ' $n$ geval waar die eiesoortige behoefte van die leerder nie voldoende in aanmerking geneem is nie. Die linguistiese kriteria vir die vasstelling van homonieme lei nie altyd tot ' $n$ ondubbel- 
sinnige klassifikasie nie. As dit 'n probleem vir taalkundiges en leksikograwe is, is dit des te moeiliker vir die teikengebruikers van 'n skoolwoordeboek om tussen homonieme te onderskei en om dan in 'n woordeboek vas te stel onder watter lemma 'n bepaalde betekenisverklaring gesoek moet word. Vergelyk die opname en bewerking van die twee homonieme klink:

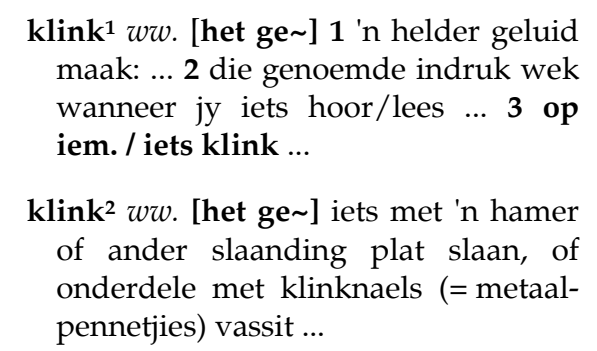

Vir die tipiese teikengebruiker van hierdie woordeboek is die verskynsel van homonimie wat hier gemerk word, nie noodwendig belangrik nie. Belangrik is dit wel om die betekenis van die woord klink wat hy/sy iewers teëgekom het, te vind. Dié gebruiker word nie gehelp in sy teksresepsieprobleem deur die afsonderlike artikels nie. Vir teksresepsie- en teksproduksiebehoeftes is dit nie belangrik vir 'n leerder om te weet of twee woorde homonieme is en of twee betekeniswaardes betekenisonderskeidinge van 'n enkele polisemiese leksikale item is nie. Die leerder moet die woord in die woordeboek vind en dan die tersaaklike betekenisverklaring of ander verstrekte inligting kan onttrek. Hier is die plasing van homonieme volgens linguistiese beginsels in afsonderlike artikels minder ter sake. Een lemma kan eerder as gidselement optree wat die gebruiker na die tersaaklike data-aanbod lei. Vergelyk in hierdie verband ook Tarp (2009).

Die vyfde probleem het te make met die aanduiding van sintaktiese kenmerke alhoewel, soos reeds genoem, die HAT Afrikaanse skoolwoordeboek in hierdie verband 'n groot verbetering op sy voorganger, die Kernwoordeboek, toon. Ons bespreek nie die waarde al dan nie van die insluiting van nog meer relevante sintaktiese data nie maar slegs die manier waarop hierdie data aangebied is - 'n werkswyse wat onses insiens (nogmaals) tot 'n te kompakte aanbod lei wat hulp aan die spesifieke teikengebruikersgroep verminder. Vergelyk byvoorbeeld weer die aanbieding, plasing en bewerking van die inskrywings iem. / iets aanlok in die artikel van die lemma aanlok:

aan·lok $w w$. [lok aan; het aangelok]

iem. / iets aanlok iets aangenaams sê/ voorstel/wys/aanbied om iemand/ iets na jou toe of na 'n plek te laat kom: kliënte aanlok met advertensies 。 Bye word deur die geur van blomme aangelok. 
Volgens die sleutel tot dié woordeboek word iem./iets aanlok hier as woordgroepe aangebied. Hierdie inskrywings word voor die betekenisverklaring geplaas en word dus die logiese adres van dié verklaring in plaas daarvan dat die lemmatiese adressering duidelik blyk. In hierdie artikel is iem./iets aanlok twee verdigte inskrywings wat eksplisiete sintaktiese data bied. In stede van hierdie plasing en aanbod kan hierdie inskrywings in 'n minder verdigte vorm as iemand aanlok en iets aanlok na die betekenisverklaring volg en wel elkeen in 'n afsonderlike reël begin. Dit is 'n gebruikersvriendeliker soekveldstruktuur en mikroargitektuur. Die bewerking van hierdie inskrywings kan dan 'n eie voorbeeldsin insluit ter illustrasie van die optrede van so 'n sintaktiese konstruksie. Hierdeur sou die aanbieding aansluit by beginsels wat voorgestel is in Tarp en Gouws (2004) met betrekking tot woordeboeke vir niemoedertaalleerders van Afrikaans, 'n gebruikersgroep wat volgens die redakteur deel vorm van die teikengroep van die HAT Afrikaanse skoolwoordeboek. Die toepassing van hierdie werkswyse sou tot die volgende aanbod kon lei:

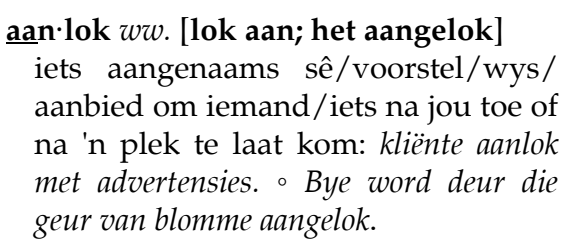

iemand aanlok: Met sy mooi woorde het hy my na sy huis aangelok.

iets aanlok: Die fluitspeler se musiek het al die rotte in die dorp na hom aangelok.

Die voorafgaande opmerkings kan slegs gemaak word omdat daar soveel verbeteringe in die HAT Afrikaanse skoolwoordeboek aangebring is in vergelyking met sy voorganger, die Kernwoordeboek, waaraan hy volgens die redakteur ' $n$ groot deel van sy bestaan te danke het.

\section{Aanbevelings}

Uit die voorafgaande bespreking is dit duidelik dat skoolwoordeboeke ' $n$ belangrike tipologiese klas verteenwoordig en veel daartoe kan bydra om ' $n$ woordeboekgebruikskultuur te vestig. Alhoewel hierdie bespreking primêr gerig is op skoolwoordeboeke vir huistaalsprekers van Afrikaans, is die bevindinge wat ten opsigte van die Afrikaanse woordeboeke gemaak is asook die volgende aanbevelings nie uitsluitlik op Afrikaans gerig nie. Die leksikografieteorie het 'n nietaalspesifieke benadering en dit geld ook die toepaslikheid van opmerkings wat ten opsigte van woordeboeke van 'n spesifieke taal gemaak word. 
Die vyf woordeboeke wat in hierdie bespreking behandel is, lewer ruimskoots daarvan bewys dat hedendaagse skoolwoordeboeke, vergelyk byvoorbeeld die Grondslagfasewoordeboek en die HAT Afrikaanse skoolwoordeboek, daarop ingestel is om aan bepaalde gebruikersbehoeftes te beantwoord. Skoolwoordeboeke toon ' $n$ duidelike invloed van die teoretiese leksikografie en hierdie invloed dra kennelik daartoe by dat die gehalte van die woordeboeke verbeter het. Die wisselwerking tussen teorie en praktyk in die leksikografie kan egter nog veel verder gevoer word om tot nog beter leksikografiese produkte te lei. Wat skoolwoordeboeke betref, is dit belangrik dat uitgewers, praktiserende leksikograwe, metaleksikograwe en opvoedkundiges as 'n span moet saamwerk om die beste moontlike skoolwoordeboeke vir die onderskeie teikengebruikersgroepe saam te stel. In hierdie verband is dit belangrik dat inligting verkry moet word vanaf die opvoedkundiges, veral opvoeders, maar ook leerders wat met die betrokke woordeboeke moet werk. Hier mag die intuïsie van die leksikograaf of uitgewer nie die enigste maatstaf wees nie. Empiriese gebruikersnavorsing is noodsaaklik.

Wat ook belangrik is, is dat enige woordeboek wat tot die kategorie van skoolwoordeboeke behoort, liefs nie in isolasie beplan moet word nie. 'n Uitgewer wat onderneem om 'n skoolwoordeboek uit te gee - al is dit slegs ' $n$ enkele skoolwoordeboek vir slegs een van die fases in die omvattender skoolprogram - behoort so 'n woordeboek as deel van 'n subtipologiese kontinuum te beplan. In hierdie beplanningsproses behoort die volle omvang van die skoolwoordeboekbehoeftes ondersoek te word en gekyk te word hoe elk van die verskillende subtipes skoolwoordeboeke ' $n$ eie gedeelte van die kontinuum moet dek. Die leksikograaf moet uiteindelik weet waar pas 'n bepaalde skoolwoordeboek binne hierdie kontinuum en hoe hou so 'n woordeboek verband met die ander woordeboeke wat ook in dieselfde kontinuum sou pas. Naas leksikografiese beginsels, onder meer kwessies soos die funksies, strukture en inhoud van woordeboeke, moet opvoedkundige beginsels ook ' $n$ rol speel. In hierdie verband is dit belangrik dat die bepalings van die relevante nasionale skoolkurrikula in ag geneem moet word. Waar woordeboekgebruik deur kurrikula vereis word, moet skoolwoordeboeke vir die betrokke leerdergroep so saamgestel word dat die tersaaklike woordeboekgebruiksvaardighede deur die raadpleging van die betrokke woordeboek ontwikkel kan word.

Die bespreking van die genoemde woordeboeke het duidelik getoon dat daar te min aandag gegee word aan 'n ondubbelsinnige spesifisering van die teikengebruikers vir wie 'n bepaalde woordeboek saamgestel word. Die kategorie "skoolwoordeboek" moet as 'n superordinaatkategorie gesien word wat in tipologiese hiponimiese verhouding tot ' $n$ verskeidenheid subordinaatklasse staan. Om slegs die superordinaatklas te identifiseer, is nie voldoende nie. Leksikograwe en uitgewers moet veel presieser as dit wees. Elke skoolwoordeboek moet eksplisiete leiding bied, liefs reeds op die buiteblad aangedui, wat aantoon vir watter gebruikersituasie en vir watter gebruikersgroep die woordeboek saamgestel is. 
In hierdie nadere spesifisering speel bepalings soos die skoolgraad, ouderdom, kenmerke van die gebruikersgroep (of hulle huistaalsprekers of nie-moedertaalsprekers van die betrokke behandelde taal is), die gebruiksituasie en daarom ook die leksikografiese funksies van die beplande woordeboek 'n belangrike rol. Wat die funksies betref, behoort dit duidelik te wees dat daar onderlinge verskille tussen woordeboeke vir verskillende grade sal wees. In die grondslagfase is die aanleer van woordeskat, dit is ter vervulling van 'n kognitiewe funksie, aanvanklik belangrik. Later speel teksresepsie en teksproduksie ook ' $\mathrm{n}$ rol. In die gevorderder grade is teksproduksie toenemend belangrik maar teksresepsie bly ter sake terwyl die kognitiewe funksie 'n mindere rol speel in algemene woordeboeke. By die beplanning van 'n woordeboek moet die tersaaklike funksies reeds geïdentifiseer en die woordeboek dienooreenkomstig saamgestel word. ' $n$ Deeglike beplanning in hierdie verband asook ' $n$ aanduiding van die teikengebruikersgroep en hulle gebruiksituasie is nie net tot voordeel van die uiteindelike of potensiële gebruikers van die woordeboek nie. Dit is grootliks tot voordeel van die leksikograaf wat die woordeboek moet opstel, aangesien duidelikheid oor hierdie kenmerke hom/haar help om 'n woordeboek tot stand te bring wat 'n reaksie is op spesifieke behoeftes van spesifieke gebruikers in spesifieke gebruiksituasies.

Daar bestaan sowel ruimte vir as behoefte aan graadspesifieke Afrikaanse woordeboeke vir moedertaalsprekers. Die voorstelle wat hier gemaak word, veronderstel nie dat die verskillende hier genoemde subtipes gelyktydig gepubliseer moet word nie. Uitgewers, opvoedkundiges en leksikograwe moet egter verdere verlore woordeboekgebruikergenerasies probeer voorkom. Om dit moontlik te maak, kan nuwe skoolwoordeboeke ter aanvulling van die bestaande woordeboeke algaande ingefaseer word. Hier speel kennis van die reeds genoemde leksikografiese kontinuum 'n bepalende rol en elke nuwe woordeboek moet daarvolgens beplan en saamgestel word. Vier verskillende woordeboeke word voorgestel om voorsiening te mak vir die omvang en verskeidenheid van die skooljare. Hierdie woordeboeke is vir graad 1-3, graad 4-7, graad 8-10 en graad 11-12. Die woordeboek vir graad 11- en 12-leerders sal ook na skool in die tersiêre opvoeding of selfs as algemene woordeboek bruikbaar wees.

Dit is belangrik dat hierdie woordeboeke telkens so saamgestel moet word dat hulle reeds vir leerders in die laagste graad van die betrokke fase bruikbaar is. Uiteraard sal daar ook meer gevorderde inskrywings wees wat die senior gebruikers ter wille is maar die geïdentifiseerde behoeftes van die leerders van elk van die grade waarvoor 'n woordeboek saamgestel is, moet bevredig kan word. Selfs data wat ter wille van die senior gebruikers ingesluit is, mag nie van so 'n aard wees dat dit die junior gebruikers se woordeboekraadplegingsprosesse benadeel nie. Die verstek moet die behoeftes van die leerders in die eerste van die betrokke grade wees. Deur verrykingsinskrywings kan data vir die meer senior leerders aangebied word. In 'n grondslagfasewoordeboek het die graad 1-leerders moontlik nog nie ' $n$ behoefte aan kollokasies nie terwyl die 
graad 3-leerders dit wel het. Kollokasies kan as sintaktiese verrykingsinskrywings aangebied word maar wel op so 'n manier dat die graad 1-leerder se soektogte nie daardeur benadeel word nie. Die aard en omvang van die definisies word eweneens deur die gebruiker bepaal. Vir die gebruikers van 'n woordeboek vir graad 11- en 12-leerders is volsindefinisies dalk nie so belangrik om suksesvolle teksresepsie moontlik te maak nie; vir die leerders van laer grade is dit wel belangrik.

Hausmann en Wiegand (1989) het reeds aangetoon dat 'n woordeboek uit minstens twee tekste moet bestaan, te wete die sentrale teks wat die hooflemmalys en artikeltrajekte bevat, en minstens een buiteteks, gewoonlik in die voorteksteafdeling aangebied, wat ' $n$ gebruikershandleiding vir die spesifieke woordeboek bevat. Vanuit die teorie van leksikografiese funksies word daar twee tipes data in 'n woordeboek verskaf, te wete primêre (funksieverwante) en sekondêre (gebruiksverwante) data. Die gebruikershandleiding is deel van hierdie sekondêre data. Te dikwels word die waarde van hierdie teks misken. Vir suksesvolle woordeboekgebruik is dit noodsaaklik dat ook die data wat hier aangebied word en die manier waarop dit aangebied word, die resultaat moet wees van deeglike beplanning, met inagneming van die teikengebruikersprofiel. Geen woordeboek behoort vandag sonder 'n gebruikershandleidingteks te verskyn nie. In nieskoolwoordeboeke bied so 'n handleiding 'n teks wat aan die teikengebruiker leiding gee oor wat in die betrokke woordeboek aangebied word en hoe die aangebode data ten beste gevind kan word. Dit moet ook in skoolwoordeboeke gedoen word maar hier moet die vlak van die leerders wat teikengebruikers is, in aanmerking geneem word. Die uiteensetting van die teks moet in ooreenstemming met die teksresepsievermoë van hierdie gebruikers wees. In skoolwoordeboeke het die gebruikershandleidingteks egter ook 'n verdere rol. 'n Skoolwoordeboek is nie net 'n instrument in die hande van die leerder nie maar ook in die hande van die opvoeder. Die gebruikershandleiding kan 'n afdeling bevat waarin die opvoeder gehelp word met raad oor hoe die betrokke woordeboek ten beste as onderrigmiddel aangewend kan word. Opvallend in die bespreekte woordeboeke is die verskil in die aard en omvang van gebruikershandleidingtekste. Dit wissel van uiters beperk tot voldoende. In die toekoms behoort daar in die beplanning en samestelling van skoolwoordeboeke veel meer erns aan hierdie tekstipes bestee te word.

Die datakeuse in enige woordeboek moet in ooreenstemming met die teikengebruikers se behoeftes gedoen word. Dit geld die data in die buitetekste, die lemmaversameling asook die mikrostrukturele aanbod. In skoolwoordeboeke sal daar ' $n$ beduidende verskil tussen die lemmakeuse vir grondslagfaseleerders en dié vir senior hoërskoolleerders wees. Skoolwoordeboeke se woordeboekkonseptualiseringplan en die daaropvolgende samestelling van die woordeboek moet dus kriteria in ag neem wat spesifiek vir hierdie lemma- en datakeuse ontwerp is. Toegang tot korpusse en die klem wat dikwels op gebruiksfrekwensie as kriterium vir die lemmakeuse geplaas word, speel ook hier 'n rol maar leksikograwe moet nie gebruiksfrekwensie soos uit 'n algemene 
korpus blyk sonder meer as enigste kriterium gebruik nie. Skoolwoordeboeke se lemmakeuse moet liefs volgens 'n toegewysde korpus gedoen word wat saamgestel is uit tekste wat dié materiaal bevat waarmee die betrokke leerders daagliks in hulle skoolleerplanne in aanraking kom. Sulke woorde wat miskien nie tot die algemene lys van hoëfrekwensiewoorde behoort nie, moet gebruik word om die korpus se hoëfrekwensiewoorde aan te vul. Ook in die lemmakeuse speel die beplande funksies van 'n woordeboek 'n wesenlike rol. Waar teksresepsie die beplande funksie is, moet 'n woordeboek 'n uitgebreider lemmaversameling hê as wanneer die klem op teksproduksie val. Teksresepsiebehoeftes vir leerders strek dikwels verder as die tipiese hoëgebruiksfrekwensiewoorde van die betrokke graad- of ouderdomsgroep. Die resultate van ' $n$ korpus se frekwensieaanduiding is nie genoeg motivering vir die lemmakeuse nie. In die beplanning van die reeds genoemde Afrikaanse woordeboek vir addisioneletaalsprekers Nuwe woordeboek sonder grense is 'n toegewysde korpus gebruik wat uitsluitlik uit data saamgestel is wat in handboeke en studiemateriaal van die betrokke graadgroepe voorkom. Hierdie korpus is teenoor ' $n$ algemene korpus gestel en aangevul met hoëgebruiksfrekwensiewoorde uit daardie korpus. Die gekombineerde korpus is vervolgens as basis gebruik vir die lemmakeuse in hierdie woordeboek. ' $n$ Soortgelyke benadering kan ook in skoolwoordeboeke vir moedertaalsprekers gevolg word.

Die mees tipiese inligting wat gebruikers aan 'n eentalige woordeboek wil onttrek, is geleë in die data wat die betekenisverklaring verstrek. Die manier waarop hierdie data in die leksikografiese definisie of betekenisparafrase aangebied word, is van bepalende belang vir die sukses van die betrokke woordeboek. In die ontwikkeling van die leksikografiepraktyk was die verskyning van die eerste uitgawe van die Collins COBUILD English Language Dictionary in 1987 van baanbrekende belang, onder meer vanweë die manier waarop die betekenisverklaring in hierdie woordeboek aangebied is. Die definisies was naamlik in natuurlike taal, soos 'n onderwyser ' $n$ woord se betekenis aan ' $n$ aanleerder sou verduidelik. Daarbenewens is die definisies ook in volsinformaat aangebied. Hierdie sogenaamde COBUILD-metode is sedertdien met vrug in talle ander woordeboeke gebruik, onder meer in die Afrikaanse aanleerderwoordeboek Basiswoordeboek van Afrikaans, asook in een van die woordeboeke wat in hierdie artikel bespreek is, naamlik Odendal se Kernwoordeboek. Hierdie tipe betekenisparafrase maak dit vir die teikengebruiker moontlik om betekenisinligting op 'n maklike manier aan die aangebode data te onttrek. Daar is geen sintaktiese hinderlikhede in die definisies nie en die didaktiese aard van die definisies verseker duidelike begrip van, maar ook insae in natuurlike sinsvorming in Afrikaans. Die Kernwoordeboek volg hier 'n werkswyse wat ongelukkig nie genoegsaam in die ander woordeboeke toegepas word nie. Ook met die keuse van hierdie definisietipe moet leksikograwe die taalgebruik in en sinskonstruksie van die betekenisparafrase aanpas by die vaardighede en taalvermoë van die woordeboek se geïdentifiseerde teikengebruikers.

Die gebruik van volsindefinisies in natuurlike taal het dikwels ruimte- 
implikasies aangesien so ' $n$ definisie dikwels meer plek nodig het as ' $n$ sinsnede of woordgroep in tipiese leksikografees. Ook van die ander aanbevelings wat in die loop van hierdie artikel gemaak is, byvoorbeeld dat die verklaring van elke betekenisonderskeiding van 'n polisemiese woord op 'n nuwe reël begin, het ruimte-implikasies. Die skrywers is bewus van hierdie werklikheid van die leksikografiese praktyk maar in die aanbieding van voorstelle in die teoretiese leksikografie moet daar in die eerste plek gewerk word met wat die beste vir die woordeboekgebruiker sal wees. Alles wat voorgestel word, is nie noodwendig haalbaar in een woordeboek nie maar uitgewers en praktiserende leksikograwe kan wel deeglik kennis neem van die voorstelle vanuit die teoretiese leksikografie. Leksikograwe moet egter daarteen waak om deur gebrek aan ruimte verplig te word om 'n te kompakte data-aanbod te gebruik wat weens ' $n$ te hoë mate van tekskondensasie of die gebrek aan 'n behoorlike mikroargitektuur die gebruiker sal benadeel in sy/haar woordeboekgebruik. Die inskrywings in skoolwoordeboeke mag nie die produk wees van 'n reduksieproses wat op inskrywings in omvattender woordeboeke toegepas is nie.

\section{Ten slotte}

Die ontwikkeling van die teoretiese leksikografie het ' $n$ besliste invloed op die leksikografiepraktyk — ook in Suid-Afrika en ook op Afrikaanse woordeboeke. Die ouer skoolwoordeboeke is dikwels saamgestel in 'n era toe die teoretiese leksikografie nog in 'n vroeë stadium van ontwikkeling was. Hulle is dus nie in dieselfde mate deur teoretiese beginsels gelei as wat vandag die geval is nie. Desondanks vorm hulle 'n noodsaaklike basis vir die verdere ontwikkeling van die leksikografiepraktyk. Danksy die wisselwerking tussen teorie en praktyk toon die meer onlangse skoolwoordeboeke vir huistaalleerders 'n groot verbetering vergeleke met hulle voorgangers. Die gebruikersgerigtheid van hierdie woordeboeke en die erkenning van die betrokke leksikografiese funksies verhoog hulle gehalte as praktiese instrumente. 'n Groter sensitiwiteit vir die diverse aard van die gebruiksituasie en die gebruikersituasie behoort verdere tipologiese verfyning in die kategorie skoolwoordeboeke mee te bring en 'n meer gerigte lemmakeuse en bewerking sal die teikengebruikers se behoeftes in 'n nog hoër mate bevredig. Die begrip van teoretiese leksikograwe vir die probleme van die praktyk en die bevestiging van praktiserende leksikograwe van die belang van teoreties gefundeerde woordeboeke kan 'n aktiewe wisselwerking verseker wat die gehalte van skoolwoordeboeke aansienlik sal verbeter.

\section{Bibliografie}

\section{Woordeboeke}

Bergenholtz, Henning et al. (Reds.). 1997. Nordisk leksikografisk ordbok. Oslo: Universitetsforlaget. 
Bosman, D.B. en I.W. van der Merwe (Reds.). 1984. Tweetalige woordeboek/Bilingual Dictionary. Kaapstad: Tafelberg.

Bosman, D.B. en I.W. van der Merwe (Reds.). 200410. Tweetalige skoolwoordeboek. Afrikaans-Engels/ Engels-Afrikaans. Kaapstad: Nasou.

Combrink, Johan et al. (Reds.). 1985². Junior verklarende woordeboek. Johannesburg: Educum.

Conradie, Ben. 1967. Verklarende Afrikaanse woordeboek vir laerskole. Kaapstad: Juta.

Conradie, C. Jac. 2001. Shuters Junior woordeboek. Pietermaritzburg: Shuter en Shooter.

De Sousa, José Martínez. 1995. Diccionario de lexicografía práctica. Barcelona: Biblograf.

Gouws, Ronél et al. (Reds.). 2010. Grondslagfasewoordeboek Afrikaans/English. Kaapstad: Maskew Miller Longman.

Gouws, Rufus et al. (Reds.). 2004. Nuwe woordeboek sonder grense. Kaapstad: Maskew Miller.

Gouws, Rufus, et al. (Reds.). 1994. Basiswoordeboek van Afrikaans. Pretoria: J.L. van Schaik.

Hartmann, R.R.K. en Gregory James. 1998. Dictionary of Lexicography. Londen/New York: Routledge.

Kritzinger, M.S.B. et al. (Reds.). 1921. Woordeboek: Afrikaans-Engels. Engels-Afrikaans. Pretoria: J.L. van Schaik.

Kromhout, Jan. 200735. Skoolwoordeboek. School Dictionary. Afrikaans-Engels. English-Afrikaans. Kaapstad: Pharos.

Louw, Phillip et al. (Reds.). 2007. Oxford Afrikaans-Engels/English-Afrikaans Skoolwoordeboek/School Dictionary. Kaapstad: Oxford University Press.

Luther, Jana et al. (Reds.). 2009. HAT Afrikaanse skoolwoordeboek. Kaapstad: Pearson Education.

Odendal, François F. 2000. Kernwoordeboek. Midrand: Perskor.

Sinclair, John et al. (Reds.). 1987. Collins COBUILD English Language Dictionary. Londen: Collins.

\section{Ander bronne}

Bergenholtz, Henning, Sven Tarp en Herbert E. Wiegand. 1999. Datendistributionsstrukturen, Makro- und Mikrostrukturen in neueren Fachwörterbüchern. Hoffmann, L., H. Kalverkämper en H.E. Wiegand (Reds.). 1999. Fachsprachen. Ein internationales Handbuch zur Fachsprachenforschung und Terminologiewissenschaft/Languages for Special Purposes. An International Handbook of Special-Language and Terminology Research: 1762-1832. Berlyn/New York: Walter de Gruyter.

Geeraerts, Dirk. 1984. Dictionary Classification and the Foundations of Lexicography. ITL Review 63: 37-63.

Gouws, Rufus H. 1989. Leksikografie. Pretoria/Kaapstad: Academica.

Gouws, Rufus H. 2007. Op pad na 'n nuwe woordeboektipologie. Southern African Linguistics and Applied Language Studies 25(3): 319-331.

Hausmann, Franz Josef. 1989. Die gesellschaftlichen Aufgaben der Lexikographie in Geschichte und Gegenwart. Hausmann, Franz Josef, Oskar Reichmann, Herbert E. Wiegand en Ladislav Zgusta (Reds.). 1989-1991: 1-19.

Hausmann, Franz Josef. 1990. Das Kinderwörterbuch. Hausmann, Franz Josef, Oskar Reichmann, Herbert E. Wiegand en Ladislav Zgusta (Reds.). 1989-1991: 1365-1368.

Hausmann, Franz Josef, Oskar Reichmann, Herbert E. Wiegand en Ladislav Zgusta (Reds.). 1989-1991. Wörterbücher. Ein internationales Handbuch zur Lexikographie/Dictionaries. An International Encyclopedia of Lexicography/Dictionnaires. Encyclopédie internationale de lexicographie. 
Handbücher zur Sprach- und Kommunikationswissenschaft 5.1-5.3. Berlyn/New York: Walter de Gruyter.

Hernández, Humberto Hernández. 1989. Los diccionarios de orientación escolar. Contribución al estudio de la lexicografía monolingüe española. Tübingen: Max Niemeyer.

Kromann, H.-P., T. Riiber en P. Rosbach. 1984. Überlegungen zur Grundfragen der zweisprachigen Lexikographie. Wiegand, H.E. (Red.). 1984. Studien zur neuhochdeutschen Lexikographie: 159-238. Hildesheim: Georg Olms.

Lagane, René. 1990. Les dictionnaires scolaires: enseignement de la langue maternelle. Hausmann, Franz Josef, Oskar Reichmann, Herbert E. Wiegand en Ladislav Zgusta (Reds.). 1989-1991: 1368-1378.

Lombard, Frederik J. 1990. 'n Metaleksikografiese fundering van Afrikaanse skoolwoordeboeke. Ongepubliseerde D.Litt-proefskrif. Stellenbosch: Universiteit van Stellenbosch.

Mabika Mbokou, Ludwine. 2006. A Model for the Macro- and Microstructure of a Yipunu-French School Dictionary. Ongepubliseerde D.Litt.-proefskrif. Stellenbosch: Universiteit van Stellenbosch.

Malkiel, Y. 1967. A Typological Classification of Dictionaries on the Basis of Distinctive Features. Householder, F.W. en S. Saporta (Reds.). 1967. Problems in Lexicography. Report of the Conference on Lexicography held at Indiana University, November 11-12, 1960: 3-24. Bloomington: Universiteit van Indiana.

Nyangone Assam, Blanche. 2006. Dictionaries as Teaching Instruments for Mother-tongue Education: The Case of Fang in Gabon. Ongepubliseerde D.Litt.-proefskrif. Stellenbosch: Universiteit van Stellenbosch.

Prinsloo, Daan J. en Gilles-Maurice de Schryver. Op koms. Do Dictionaries Define on the Level of their Target Users? A Case Study for Three Dutch Dictionaries. International Journal of Lexicography.

Tarp, Sven. 2000. Theoretical Challenges to LSP Lexicography. Lexikos 10: 189-208.

Tarp, Sven. 2008. The Third Leg of Two-legged Lexicography. Hermes. Journal of Linguistics 40: 117131.

Tarp, Sven. 2009. Homonymy and Polysemy in a Lexicographic Perspective. Bergenholtz, Henning en Thomas Herbst (Reds.). 2009. Classifications in Linguistics and Lexicography. Special Issue of Zeitschrift für Anglistik und Amerikanistik 57(3): 289-306.

Tarp, Sven. 2010. H.A. Welker and Pedagogical Lexicography. Lexikos 20: 730-749.

Tarp, Sven en Rufus H. Gouws. 2004. Wie leer wat uit Afrikaanse (aan)leerderwoordeboeke. Tydskrif vir Geesteswetenskappe 44(4): 276-298.

Tarp, Sven en Rufus H. Gouws. 2008. A Lexicographic Approach to Language Policy and Recommendations for Future Dictionaries. Lexikos 18: 232-255.

Welker, Herbert Andreas. 2008. Panorama geral da lexicografia pedagógica. Brasília: Thesaurus Editora.

Zgusta, Ladislav. 1971. Manual of Lexicography. Den Haag: Mouton. 